\title{
Assessing Integration of Infrastructure 2.0 Tools in Open Learning Websites: Highlighting a Need for Purposeful Design
}

\author{
Anastasis Petrou \\ University of East London, London, UK
}

t.petrou@uel.ac.uk

\begin{abstract}
This paper employs a heuristic evaluation checklist based on socio-cultural theory to assess open learning opportunities in the Visible Web where further integration of Infrastructure 2.0 or WEB 2.0 tools, accompanied by purposeful design (i.e. design which clearly ties integration and use of tools to achievement of specific learning outcomes), could improve the quality of interaction and ultimately of learning. The selected examples of websites are just four of many on the Visible Web offering open learning opportunities and where purposeful design is / could be used to some degree; the paper uses the four websites to draw more attention to the importance of deploying WEB 2.0 tools supported by purposeful design. The paper highlights Infrastructure 2.0 implications of interactive, instructional technology design (IITD) and identifies issues and areas for future research in terms of how purposeful integration of Infrastructure 2.0 tools could further enhance open learning.
\end{abstract}

Keywords: Open Learning, Learning Enhancement, Visible Web, Interactive and Instructional Technology Design (IITD), Infrastructure 2.0 Tools, Purposeful Design

\section{Introduction}

The herein reviewed websites are just four examples of websites on the WWW which could benefit from purposeful design used to enhance the quality of interactive open learning opportunities that they provide. The paper's investigation involves use of a socio-cultural heuristic evaluation checklist to assess areas for integrating WEB 2.0 tools desirable for learning enhancements in each of the four open learning websites. The socio-cultural heuristic evaluation checklist focuses on learning design as opposed to drawing out extensive usability issues in a website. The paper highlights Infrastructure 2.0 implications of purposeful design in open learning websites and identifies areas for future research. The four selected websites are:

- BBC Learning http://www.bbc.co.uk/learning/

- Intute - Resource Discovery Network http://www.intute.ac.uk/

Material published as part of this publication, either on-line or in print, is copyrighted by the Informing Science Institute. Permission to make digital or paper copy of part or all of these works for personal or classroom use is granted without fee provided that the copies are not made or distributed for profit or commercial advantage AND that copies 1) bear this notice in full and 2) give the full citation on the first page. It is permissible to abstract these works so long as credit is given. To copy in all other cases or to republish or to post on a server or to redistribute to lists requires specific permission and payment of a fee. Contact Publisher@InformingScience.org to request redistribution permission.
- MIT openCourseware http://ocw.mit.edu

- National Learning Network http://www.nln.ac.uk/materials/

The author randomly selected these four websites from a list of websites he had developed to learn about open learning opportunities in the Visible Web and to reflect on purposeful design. The four websites were simply selected to aid 
with critical discussion of purposeful design and integration of WEB 2.0 tools rather than to specifically highlight shortcomings with the four websites, although the paper's discussion does suggest areas of improvement for the four websites.

\section{Paper Structure}

1. Introduction

2. The Bigger Problem

3. Infrastructure 2.0

4. Evaluation Framework

5. Evaluation of the Four Websites

6. Implications and Future Research

7. Conclusions

8. References

\section{The Bigger Problem: Not Enough to Just be on the Internet}

The millions of Internet-based websites in existence today can be examined in terms of what tools they use to provide connectivity, to promote user interaction and to provide fully online services. The extent of use of WEB 2.0 tools for connectivity, interaction and services tends to place a website's learning environment in either the Internet, or the Web or the Cloud group, respectively, and even worse for the four under review in-between groups of worlds. The "world" designation is used here to suggest that various online tools aid a user in creating a community or a learning world or worlds for social interaction.

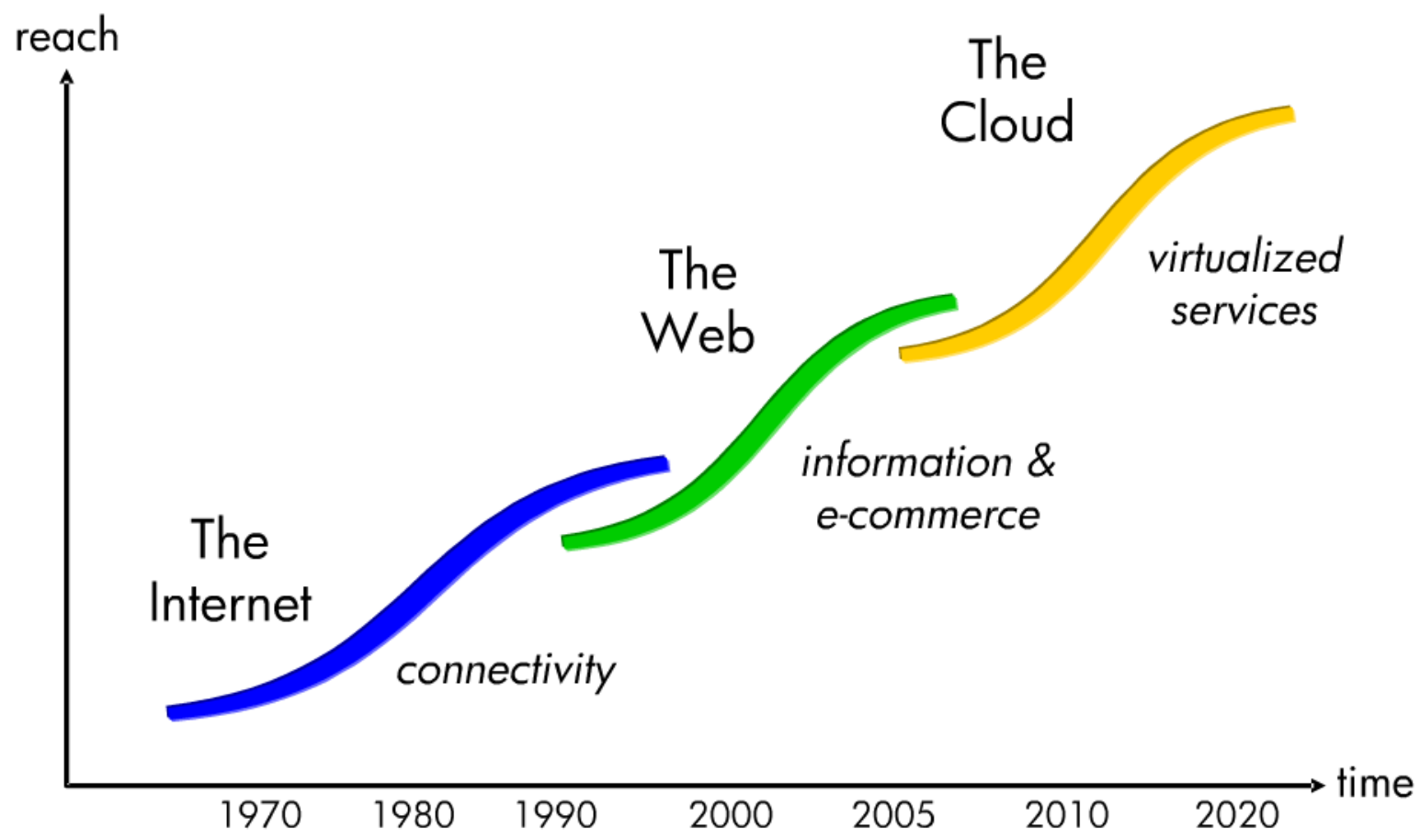

Figure 1: The Third Generation (Agati, 2009, p. 3) 
An "in-between worlds" placement is an ambiguous place to be in terms of open learning services, interactivity in learning and brand loyalty as illustrated by the use of Figure 1 by Agati $(2009$, p. 3) who discusses the benefits of Infrastructure 2.0. The concern about the four reviewed open learning websites is the extent to which they could make further use of WEB 2.0 / Infrastructure 2.0 tools driven by purposeful design and the interactive learning benefits they could provide from such use and design of tools for their learners.

\section{Infrastructure 2.0}

But what exactly is Infrastructure 2.0 and what is its relationship to social networking and WEB 2.0? The Internet became a reality in the 1960's and its current existence serves to support the WWW which burst upon the scene in the early 1990's with the introduction of MOSAIC, the first publicly available browser. Currently, however, global society is moving past the WWW towards Cloud Computing and the "Cloud" is starting to replace WWW as a metaphor for global communications. Infrastructure 2.0 is a complex placeholder for hardware and software capabilities which support the Cloud and related activities including social networking and WEB 2.0 applications and tools for communication. Discussions about Cloud Computing include mentions of Infrastructure 2.0, social networking, data centres rationalisation and data virtualisation, among other things. Macvittie (2010) offers the following clarifications as to what Infrastructure 2.0 and Cloud Computing are all about. According to Macvittie (2010) "Cloud computing takes the infrastructure layer services and orchestrates them together to codify an operational process that provides a more efficient means by which computing, network, storage, and security resources can be provisioned and managed. This, like Infrastructure 2.0, is an enabling technology." (http://cloudcomputing.sys-con.com/node/1535044). In terms of Infrastructure 2.0, Macvittie has this to say: "It is the way in which traditionally disconnected (from a communication and management point of view) data center foundational components are imbued with the ability to connect and collaborate ... Infrastructure 2.0 is about making the network smarter ..." (http://cloudcomputing.sys-con.com/node/1535044).

Infrastructure 2.0 is the foundational layer which supports not only Cloud Computing, but also application delivery, security and the network itself which makes cloud computing possible. Greg Ness (interviewed by Wolfe, 2010) states that "Infrastructure 2.0 is essentially about the evolution of today's network from the old world of middlemen--an age of business where you had lots of people and paperwork and processes. We're now transferring from that age of IT to an age of automation."

(http://www.informationweek.com/news/globalcio/interviews/showArticle.jhtml?articleID=2223 00500). Infrastructure 2.0 stands for enablement, connection and collaboration, among other core things. Without Infrastructure 2.0, WEB 2.0 applications will not be possible and neither would cloud computing. Modern businesses as well as private, educational and third sector organisations have much to benefit from upgrading services to a platform empowered by Infrastructure 2.0 capabilities. The above technical, management and service background serves as a backdrop for social networking as it is explored in this paper. It is because of the evolution of Infrastructure 2.0 and the things it supports such as WEB 2.0 and social networking tools that a lot of the interactive and open learning activities available on the Visible Web are possible. An interactive, open learning experience can be delivered to anyone visiting a website, without the involvement of special e-learning software or custom-made e-learning platforms and login areas, although there might still be reasons for the use of passwords and user names, but without a pecuniary motivation involved to limit who at the end is granted access. Although, there are Invisible Web types of functionalities in two of the four websites (i.e. there is a password protected area) examined herein, the abundance of otherwise available or open access learning materials really justify the investigation of how these websites utilise instructional design to deliver what they are delivering on the surface of the Web to any learner who visits each website. 


\section{Evaluation Framework}

\section{Social Networking's Big Players and Biggest Audience}

In his discussion of social networking history, Nickson (2009) provides the following launch dates: Friendster - 2002, Linkdln - 2003, MySpace - 2003, Facebook - 2004, Twitter - 2006. With 10 million active users, Friendster was considered as the biggest social network service provider in 2004. Shortly after, however, it was dethroned from its number one spot by MySpace (Perdu, 2008). Other major players also exist today. "Facebook and Twitter are well-known social network services" (Thatcher, 2009, p. 2).

The current king of social network services is Facebook. During 2010, Facebook grew from 150 million in 2009 to 400 million active users worldwide and it still growing at a fast pace (Social Media Graphics, http://socialmediagraphics.posterous.com/facebook-compared-to-countries). Facebook has a global reach, with 70 percent of users outside the USA. (Burcher, 2010). A large group of online users and those most likely to use social networks and social network devices for staying in touch with friends is young people who are also currently going through the education system. These are the people who grew up with the current WEB 2.0 technologies which support social networking sites, Facebook, MySpace, YouTube, blogging, instant messaging, etc., all of which are popular with young people aged between 14-24 or people who are currently going through the education system.

There is no doubt that teachers are noticing they are working with students behaving much differently than previous generations. These are young people brought up in an ICT prevalent world. As Ashraf (2009) notes "this new world of apparently always-on/never-off; always-connected and listening in isolation but somehow collaborating online [...] is packed full of powerful tools and technologies, many of which provide platforms for our students to share/exchange information about themselves (social networking), searching and bookmarking information, as well as providing numerous vents for self-expression; such as MySpace, Bebo, Flickr, Wikis, blogs, podcasts, Wikipedia, Delicious, YouTube and Facebook." (p. 343). A number of these technologies have found their way into online and tertiary classrooms as assignments are now regularly given which require a blog, use of a WIKI, creation of a pod cast, use of a discussion forum and use of a variety of other social networking tools. Students are already prepared and willing to use these technologies. But the problem is, as Towell (2009) notes, that a digital [culture] divide may exist now between teachers' ability to use the new interactive set of technologies in the classroom and students' ease with such technologies. On the plus side, WEB 2.0 and social networking technologies are for the most part easy to use and user friendly. Social networking sites and tools, however, are not by themselves a substitute for teaching and/or learning with a purpose. Their use in classrooms must be approached with a plan and an instructional design theory of some kind in mind. For example, WIKI is a good tool to use in first year information systems modules where you want to give students a taste on how to be part of a group in a classroom and also create and edit a small web page where they can link up with other students' pages on the WIKI.

\section{An Architecture of Participation and Interaction}

Doyle (2007) defines a social network as "a collection of interconnected people." (p. 61). The definition does not address how such collection of people is interconnected. Edutopia (n.d.) states that a social network "is software that allows people to come together around an idea or topic of interest." (http://www.edutopia.org/how-use-social-networking-technology). The precursor of today's social networking technologies is the linked network (Internet) of mainframe computers and bulletin board systems (BBS) which supported newsgroups in the 1970's and 1980's (Nickson, 2009). Yesteryear's cumbersome interfaces have been replaced by the easier to use 
interfaces users interact with in current social technologies. These social technologies "snitch, or look and tell" one when friends and messages are available online, among other things. Social networking technologies and services are supported by WEB 2.0 (O'Reilly, 2004a) or an "architecture of participation ... [describing the nature of] ... systems that are designed for user contribution" (O'Reilly, 2004b). "Social networks are formed as members [of social network services such as Facebook] link their web pages to those of their friends and search through the vast number of sites in search of new friends who might share common interests." (Barsky \& Purdon, 2006, p. 27).

\section{Other Criteria}

According to Tan and Tung (2003), typically one of three general approaches is used in the design and evaluation of websites. These are: the Technology Acceptance Model (TAM), Flow Theory, and Human-Computer Interaction (HCI). Reflecting on these three approaches, Tan and Tung (2003) identified 14 categories for website evaluation. However, multimedia, audio, knowledge sharing and generally WEB 2.0 features which support and enhance social interaction through the use of language and human communication are not included in the 14 categories. A focus on users and learners and how they learn individually and in collaboration with others, however, is very much needed. Such learning can be examined using adult learning and instructional design theory along with Culture as a research framework. Hofstede (2005) describes culture as the "collective programming of the mind which distinguishes the members of one category of people from another." (p. 51). George et al. (2007) indicate that "Culture is a collective phenomenon because it emerges among people who live in the same social context." (p. 5).

Arno (2010) suggests that design of cross-cultural websites must use sympathetic colours so as not to alienate large segments of the audience. Furthermore, he discusses use of Cascading Style Sheets (CSS) because such practice "will allow you to separate the content of your website from its design and layout, creating a site that can be easily translated and adapted for different languages and cultures." (Arno, 2010, CSS \& Encoding section). Instructional design can be used to tailor a balance or a good blend between providing active learners from different cultures with the means for content or information retrieval and enabling them to engage in active learning activities framed by learner-oriented constructivist and cultural learning theories.

Markussen and Krogh (2008) discuss Blending Theory as a way to do more work in the area of cultural frame shifting in interaction design. Although the Blending Theory they proposed is a bit abstract for easy application, what it is important to note are the social and cultural elements incorporated in interaction design for technology environments. Socio-cultural Learning Theory has been a learner-centred framework for learning and technology development for some time in education. According to Whipp, Eckhman and van den Kieboom (2005) “... socio-cultural learning theory is socially and culturally situated in contexts of everyday living and work" (p. 37). Vygotsky (1978), known for his proximal development zone construct, argued that children and adults learn best by benefiting from the mentoring efforts of another person or a more experienced peer both of which can be enabled through use of social networking tools for keeping people in touch. Other noted advocates of socio-cultural learning theory are Brown, Collins, and Duguid (1989), Lave and Wenger (1991), Moll (1990), Rogoff (1990), Tharp and Gallimore (1988), Wertsch (1991). Social interaction and interaction tools such as those provide by WEB 2.0, knowledge sharing mechanisms, context, situated learning, and language are important from the socio-cultural learning theory point of view. Herein, instructional design constructs derived from the work of Vygotsky (1978), Knowles (1968, 1975, 1980, and 1984) and Gagne (1985 and 1992) are brought together, particularly how different instructional events, such as use of feedback, objectives, and well-organised content can help adults learn in independent ways and within different socio-cultural learning conditions and contexts. The full list of the nine instructional 
events is as follows: gain attention, inform learner of objectives, stimulate recall of prior learning, present stimulus material, provide learner guidance, elicit performance, provide feedback, assess performance and enhance retention transfer. (Robert Gagne's Nine Events of Instruction, http://ide.ed.psu.edu/idde/9events.htm).

Table 1 - Heuristic Evaluation Checklist: 10 Criteria

\begin{tabular}{|c|c|}
\hline 10 Criteria & Brief explanation of what to look for in each instance \\
\hline Navigation & easy, complicated, confusing, menu location, etc. \\
\hline Knowledge Sharing & $\begin{array}{l}\text { available, not available, type of knowledge being shared, } \\
\text { etc. }\end{array}$ \\
\hline $\begin{array}{l}\text { Social Interaction \& Network- } \\
\text { ing }\end{array}$ & tools, extent, scope, etc. \\
\hline Active, Independent Learning & opportunities to learn through own initiative and exploration \\
\hline Multimedia (and Language) & media, audio, languages available, etc. \\
\hline Different Audiences & which age groups and learning interests are supported, etc. \\
\hline Aesthetics & look and feel of website, colours, design, style, fonts, etc. \\
\hline Instructional events & use of objectives, learner guidance, performance, feedback \\
\hline Content & scope of content, text chunking, links to the outside, etc. \\
\hline Search / User Data Storage & browsing vs. full search facilities, technology used, etc. \\
\hline
\end{tabular}

The criteria account for a number of instructional design concerns, but not for all nine, and not for all possible Infrastructure 2.0 issues either due to lack of time and space. On Table 2, which provides a quick summary of the application of the above criteria in the evaluation of the four learning websites, the $\sqrt{ }$ mark is used to indicate that a website was functional and no broken links were evident during evaluation. As the summary in Table 2.0 and the discussion in the next section indicate, both social interaction and social networking facilitated by each website are low and user data storage facilities are not offered in any of the evaluated websites. Preference seems to be given to interaction of people with information structures (a WEB 1.0 communication and information provision approach). The above findings will be discussed in more detail in the implications section.

\section{Evaluation of Four websites}

The BBC URL is an entry point to a number of interconnected websites on a variety of knowledge and learning domains and interest areas, but with each website using a slightly different design template. Navigation in each website is easy to follow. To the right of the learning home page (http://www.bbc.co.uk/learning/), and under learning resources for everyone, there are four different links (adult learners, schools, parents and teachers). Below the before-mentioned four links, two other link areas are available and are titled: learning about bbc.co.uk and learning around the web. This is a great idea to juxtapose links for local / national and global content in two adjoining sections. To the left of the home page, there are two links titled: "most popular subjects now" and "more subjects." I checked out the "most popular subject, as I was curious to know of the perusal habits of other people. 
My initial disappointment at the lack of a BBC log in area was washed away when I discovered all of the fun, interactive, open learning activities the BBC offers in the About BBC Learning web area. One of the available categories is Bitesize and it offers a variety of study and exam preparation materials for different age groups and audiences. After I had some fun with KS1, KS2 and KS3 Bitesize activities, I checked out the GCSE Bitesize activities. There are 20 individual GCSE preparation areas each using multimedia and interactive activities to make learning fun. Learner study is supported with audio, video, games and message boards. The BBC Learning area is the web area reserved for online learning, support and advice, and although activities are not strictly tied to a formal assessment process they should be of great value to any motivated active learner. Supporting the idea of designing websites for positive and effective use (Constantine, 2004) BBC websites were designed with the objective in mind it seems to delight their users in terms of the depth, quality and interactivity of their online spaces. Generally speaking, the $\mathrm{BBC}$ websites work well as they are linked, nicely-designed and well-resourced in terms of what they offer to learners / audiences of all ages. The BBC websites, particularly the BBC Learning area, are well-conceived from a usability-oriented point of view in that information is broken out in small chunks, there is a good navigation scheme and lots of interactive features render use of the websites a fun user-centred experience. While this URL http://www.bbc.co.uk/learning/ is a good entry point to the BBC websites, I prefer this one http:/www.bbc.co.uk/learningoverview/ instead as entry point, as it provides a better learning overview. Plus, it provides a quicker entry into the open learning area, albeit not a "log in" type of online learning area, which was very exciting indeed in terms of depth and design.

My first impression of the Intute - Resource Discovery Network website was that it looked and felt pretty flat and it lacked depth. However, upon closer inspection, I discovered that each category on the home page led to a number of pages with content in various sub-categories. Under the All Services link, there are some very interesting services, too many to list here, but a few examples of different resources are as follows:

- Guide for astronomy

- World Guide providing information on 270 countries,

- Subject guide on a variety of subjects,

- Virtual Training Suite for students to improve their Internet search skills,

- RSS newsfeeds, podcasts with prominent researchers,

- North West Film Archive

- and a variety of other excellent services.

There are no restrictions as to who may register for a "MyIntute" account so I registered for one, but funding for Intute - Resource Discovery Network expires in 2011, although alternatives for access are being developed. In terms of instructional re-design for the Intute - Resource Discovery Network website, it would be best that the website be re-designed around the many services it provides to ensure that users / learners have an easier time discovering the very useful resources on offer on this website. The content is good, but the services area provides a lot of interactive features which active learners would want to know right away, and actually such interactive services might be the reason why many people would be coming back to the site for many a visit. The guides provide significant informational value, but they are not tied to any specific instructional events per se and even if they are, the instructional and learning purpose it is not immediately apparent. On the other hand, this website can be considered as a support for learning, an area for resource discovery, as opposed to shaping learning in terms of a purposeful use of instructional events. 


\begin{tabular}{|c|c|c|c|c|}
\hline $\begin{array}{l}\text { Website } \\
10 \text { Criteria }\end{array}$ & BBC Learning & $\begin{array}{l}\text { Intute - Re- } \\
\text { source Discov- } \\
\text { ery Network }\end{array}$ & $\begin{array}{l}\text { MIT open- } \\
\text { Courseware }\end{array}$ & $\begin{array}{l}\text { National Learn- } \\
\text { ing Network }\end{array}$ \\
\hline Navigation & Good & $\begin{array}{l}\text { Could be better: } \\
\text { highlight user } \\
\text { services }\end{array}$ & Good & Basic \\
\hline $\begin{array}{l}\text { Knowledge Shar- } \\
\text { ing }\end{array}$ & $\begin{array}{l}\text { Send page to a } \\
\text { friend (could be } \\
\text { better) - }\end{array}$ & $\begin{array}{l}\text { Intute blog, and } \\
\text { RSS feeds and } \\
\text { podcasts }\end{array}$ & $\begin{array}{l}\text { OPEN Learning, } \\
\text { but no degrees, } \\
\text { classroom access } \\
\text { or direct feedback } \\
\text { involved. }\end{array}$ & $\begin{array}{l}\text { Possible through } \\
\text { the materials and } \\
\text { learning / tutor } \\
\text { handbooks. }\end{array}$ \\
\hline $\begin{array}{l}\text { Social Interaction } \\
\text { and Networking }\end{array}$ & $\begin{array}{l}\text { Mostly people } \\
\text { interacting with } \\
\text { learning struc- } \\
\text { tures.- }\end{array}$ & $\begin{array}{l}\text { May be possible } \\
\text { in the blog, etc. } \\
\text { - }\end{array}$ & $\begin{array}{l}\text { Mostly people } \\
\text { interacting with } \\
\text { learning struc- } \\
\text { tures.- }\end{array}$ & $\begin{array}{l}\text { Perhaps possible } \\
\text { through interac- } \\
\text { tion in the log in } \\
\text { area - }\end{array}$ \\
\hline $\begin{array}{l}\text { Active, Independ- } \\
\text { ent Learning }\end{array}$ & Yes & Partially - & Yes & Yes \\
\hline $\begin{array}{l}\text { Multimedia }(M) \& \\
\text { Language (other } \\
\text { than English) (L) }\end{array}$ & Yes, (M) & No - & $\begin{array}{l}\text { Yes, audio/video } \\
\text { supporting course } \\
\text { areas \& L (6 lan- } \\
\text { guages) }\end{array}$ & No - \\
\hline $\begin{array}{l}\text { Different Audi- } \\
\text { ences }\end{array}$ & Yes & $\begin{array}{l}\text { Professional } \\
\text { audience - adult } \\
\text { learners }\end{array}$ & $\begin{array}{l}\text { adult and young } \\
\text { adult (High } \\
\text { School) learning }\end{array}$ & $\begin{array}{l}\text { Different levels } \\
\text { of learning }\end{array}$ \\
\hline Aesthetics & $\begin{array}{l}\text { Neutral, but } \\
\text { pleasant }\end{array}$ & $\begin{array}{l}\text { Neutral, but } \\
\text { pleasant }\end{array}$ & $\begin{array}{l}\text { Pleasant, albeit } \\
\text { neutral colours } \\
\text { are used. }\end{array}$ & $\begin{array}{l}\text { Basic - interest- } \\
\text { ing colour on } \\
\text { home page. }\end{array}$ \\
\hline $\begin{array}{l}\text { Instructional } \\
\text { Events (objectives, } \\
\text { feedback, guid- } \\
\text { ance, practice, etc.) }\end{array}$ & $\begin{array}{l}\text { Interactive learn- } \\
\text { ing activities with } \\
\text { practice. }\end{array}$ & $\begin{array}{l}\text { Guides are use- } \\
\text { ful for learning, } \\
\text { but no feedback } \\
\text { - }\end{array}$ & $\begin{array}{l}\text { Course materials, } \\
\text { but no feedback } \\
\text { process. - }\end{array}$ & $\begin{array}{l}\text { Handbooks / } \\
\text { learning materi- } \\
\text { als use objec- } \\
\text { tives. }\end{array}$ \\
\hline Content & $\begin{array}{l}\text { Local / global and } \\
\text { rich }\end{array}$ & Various levels & Good & Good \\
\hline $\begin{array}{l}\text { Search / user data } \\
\text { storage }\end{array}$ & Yes / No - & Yes / No- & Yes / No- & $\begin{array}{l}\text { No - Browsing / } \\
\text { Hyperlinks - / } \\
\text { No- }\end{array}$ \\
\hline Rating & $\sqrt{---}$ & V----- & $\sqrt{---}$ & ل \\
\hline
\end{tabular}

The MIT openCourseware website is impressive in terms of the content it provides and the "open" cultural purpose it serves for learning. The author's fondness for "open" approaches to computing and learning might have prevented him from being too critical over this website's design, although resources are pretty easy to find and the use of video and audio in courses is com- 
mendable. And of course, the idea of sharing knowledge at this cultural level is really fantastic. There are 200 available courses one may select from in order to engage in independent learning. This website offers study materials which high school students and teachers may find useful. A good menu option to the left of the home page, however, was the Translated Courses providing access to courses in six languages (Traditional Chinese, Simplified Chinese, Thai, Spanish, Portuguese and Persian). Although the course offerings on the MIT openCoursware website are not linked to formal assessment processes, they do support meaningful and fun learning for active learners. While on principle a re-design of the MIT openCourseware could be beneficial, in the large scheme of things, and in terms of the purpose this site servers, a re-design is not absolutely necessary. The website's organisation is functional and its structure serves the purpose the website has been designed to support. That being said, whatever learning is possible online it is not linked to a purposeful instructional feedback process.

At first, the National Learning Network website was the author's least favourite in terms of its design and presentation because of the somewhat imposing colours on the home page. However, a perusal of the materials listed under the four categories (ACL, Basic/Core/Key Skills, Subjects and Vocational) demonstrated a substantive content which compensated for the not so attractive home page. Furthermore, the instructional materials available for study are nicely structured, use clear learning objectives, and potentially provide for good learning opportunities. A preliminary review of the pdf study materials available on the website shows that they provide good instructional content and various learning activities all of which are clearly presented and easy to follow. In order to register to gain access to the "Log-in" area for the National Learning Network one needs to have an "organisation password" which the author did not have. Subsequently, no comment is possible on what else might be available in a protected area (Invisible Web section) in terms of feedback and assessment processes and on existence of any other instructional events. In terms of a re-design, it would be preferable that the home page be redesigned with learners in mind and what they need to do on the website. The four categories on the home page are not very informative and they also need to be reconsidered. An email notification / alert service might be good to add for potential learners to sign up to receive mobile telephone alerts when a new study area is added or one is modified. From an instructional design point of view, handbooks / learning materials for subjects are professionally produced with content well-structured and based on objectives; objectives are one of the nine instructional events according to Gagne (1985) and Gagne et al. (1992). No further instructional evaluation about the National Learning Network's elearning area is possible for this paper, however, as an institutional password is needed to log in to access content for a particular subject's page (and it is not clear based on the website exactly what activities are available after one logs in; potentially there could be a full spectrum of elearning activities incorporating a variety of instructional events).

\section{Implications and Future Research}

\section{In-Between Worlds}

As indicated in a previous section, social networking tools such as blogs, discussion forums, WIKIs and a variety of others, are not a magic bullet for learning by themselves. Their use must be preceded by a thoughtful reflection of what outcomes learning ought to achieve in a given learning website and for the particular audience it tries to reach. Unfortunately, all four evaluated websites do not offer much in terms of social interaction and social networking, as they all privilege interaction of people with information structures which is a WEB 1.0 remnant in terms of communication and information provision. While the $\mathrm{BBC}$ website is particularly rich in information and it is well-designed in many respects, it also receives low scores for social networking. All four websites are in essence designed with WEB 1.0 and not WEB 2.0 in mind. In essence, 
these four learning websites, as well as many other websites, are caught in-between WEB worlds; an aging, yesteryear WEB 1.0 world and the emerging WEB 2.0 world. The four herein reviewed learning websites, as well as many others on the WWW today, are, in terms of their technology and design, situated in the space formed by the respective edges of the green and the yellow curves in Figure 1. Although this study used only four learning websites, the in-between WEB worlds research confirmation is yet another manifestation of the ongoing need for organizations to keep up with emerging technologies and to put in place plans for migrating from the old to the new in order to provide improved learning experiences which must be well designed. This study is not necessarily advocating a Cloud-like perspective in education and learning services. At a basic level, an adaptive and thoughtful approach on issues of infrastructure in general is needed and with a specific concern of how best to deliver learning services and computing support to mobile, networked and active learners. The instructional events construct, mentioned in previous sections of this paper, is a complex placeholder of instructional design activities in nine areas each of which is in itself a dynamic research path for understanding how each generation of learners learn under different conditions and cultural contexts. As educators, teachers and / or facilitators for learning, we would always want to know how to orchestrate well-designed assessments, how to put together sound objectives, how to give meaningful feedback and how to design practical sessions of learning which are of value to our learners. But, successful implementation of instructional events, which fit different learning conditions, also hinges upon our ability of being adaptive and ready to learn more about the world around us and also about how to use the best and most appropriate instructional technology available to deliver learning of value to our students and to help them make sense of the world around them. The ubiquity of technology and the presence and use of modern WEB 2.0 applications by students makes it even more imperative that technology is used about of education and in learning websites.

\section{Ubiquitous Interaction}

As technology users, many of us have experienced a number of turning points in technology's history which have redefined what it means to use technology for educational and personal purposes. Availability of Mosaic at the beginning of the 1990's ushered in the WWW. Similarly, the launch of social networking services ushered in a widening of participation in WEB 2.0 technologies, such as instant messaging, discussion forums, blogs and social networking sites and tools. According to Margaryan and Littlejohn (2008) "The concept of Web 2.0, coined by Tim O'Reilly in 2004 (O'Reilly, 2004), has quickly taken hold, denoting a new generation of web-based tools, environments, and services that enable new forms of collaboration and knowledge sharing between users." (p. 1). Also, developments in mobile technologies support anywhere and anytime social networking and interaction and as long as users are logged into a network service provider. However, as we have seen from the evaluation of the four websites, WEB 2.0 has not fully reached where it needs to be to impact learning. This is not the case simply on the Visible Web, but also for applications and learning environments on the Deep Web.

Availability of the following five technical elements is essential in order to enjoy a positive user experience on a learning website and to introduce needed Infrastructure 2.0 improvements: Network, Open Source, Publishing Platform, User Generated Content, and Search (along with user data storage).

\section{Network}

A network in this section refers to WEB 2.0 technologies and applications supporting information flow and user interaction online. Usually, the network consists of countless servers, clients and sophisticated software and routers which facilitate data transmission and redundancy in the net- 
work. Data from databases and files can be dynamically displayed on pages through the use of new languages such as ASP, PERL, and ColdFusion to mention a few.

\section{Open source}

Perhaps what characterises current social networking and WB 2.0 technologies is their reliance on free, open source software which anyone can download and modify for their unique purposes. MOODLE which supports virtual learning and use of discussion forums, WIKIS and blogging uses open source software and can be downloaded for use at no charge. Potentially, anyone could start the next computing revolution using open source software.

\section{Publishing platforms}

Social networking services such as Facebook and Twitter are publishing platforms for the new age. They offer a new way of getting information out there and this can have its pluses, such as ease of publication and distribution, and minuses, such as questionable quality and possibility of miss-use. Educational software must offer opportunities for students to "publish" their educational products online and for the purposes of peer review and feedback from their cohort during tutorials and practical sessions.

\section{User generated content}

Anytime one responds to a friend's text message he or she creates and distributes user generated content. Anytime a user posts an opinion on a chat room, once again user generated content is created and distributed online. Facebook's personal pages are filled with user generated content as are blogs, WIKIS, Twitter text messages and discussion forums in any virtual learning environment for a tertiary and online module for a programme at a University.

\section{Search capabilities}

Many new search engines use WEB 2.0 technologies to mash up information from many sources on special interest areas. For example, FundooWeb (http://fundooweb.com) offers a quick way for searching such sources as Yahoo, flickr, Amazon and offers a variety of news services and access to Facebook. Another interesting search engine is flickr-storm (http://www.zoom.com/flickr-storm ) which helps with finding great looking images. A search for Denver producers a number of images, including an image of Denver International Airport (DIA) which is the largest international airport in the United States.

\section{Cognition and the Architecture of Participation}

Social networking interactive technologies are not difficult to use. However, anyone who has ever watched a teenager text in lightning speed should not fail to see the high level of coordination and cognitive agility the simple task of texting requires. Young people, between the ages of 14-24 referred to as Digital Natives, NetGen, Generation Y, and Homo Zappiens (Howe \& Strauss, 2000; Margaryan \& Littlejohn, 2008; Oblinger \& Oblinger, 2005; Prensky, 2001; Tapscott, 1998) require that teaching is not solely based on a lecture and a power point presentation. According to Margaryan and Littlejohn (2009), "it has been claimed that this generation, who have grown up with ICT, have sophisticated technology skills and a whole new set of cognitive capacities." (p. 1) sharpened by their use of WEB 2.0 and social networking technologies. This new set of cognitive abilities must be put to good use by utilising the "architecture of participation" and collaboration offered by WEB 2.0. 


\section{Interactive Activities}

Social networking interactive technologies must be used more in education, as this will help students feel more connected, and yet independent, and help sharpen their computing abilities even more. Teachers could use more social networks technologies to create private online networks for teaching and learning. Since "social networking and social media motivate students to learn independently, primarily outside of the school day" (Johnson, 2009, p. 2) then they can also be used for a smoother extension of classroom activities into study hours at home by making more content accessible via mobile devices. In terms of future trends, we need more interactive teaching technologies which can utilise mobile technologies and tools such as the mobile phone and personal digital assistants to enhance interactive learning in and outside the classroom. Using interactive classroom pedagogies in large classes can be difficult (Freeman and Blayney, 2005). People retain more knowledge if they actively participate in the learning process by doing an activity and applying the presented concept to a real problem and to enhance study on their own time online as use of the BBC website demonstrates.

\section{Conclusions}

This paper used a heuristic checklist of 10 Socio-Cultural Learning Theory and instructional design criteria to evaluate further integration of WEB 2.0 tools in four open learning websites. All websites offer significant amounts of content, but each website's design can best be described as existing in-between WEB worlds framed by functionalities offered by WEB 1.0 and WEB 2.0 technologies. Use of media, audio and language facilities in three of the websites should be noted as a step in the right direction. But, all websites can benefit from instructional re-design to enhance interactive learning, although the $\mathrm{BBC}$ websites offer high levels of interactivity particularly in the BBC Learning web area. Purposeful re-design of learning areas in each of the websites could utilise additional interactive technologies and interactive learning facilitation features, including additional WEB 2.0 tools to better address the needs of diverse audiences and to account for the situated contexts in which information retrieval, interaction and learning activities, active learning and instructional events unfold.

\section{References}

Agati, M. (2009). Infrastructure 2.0: The infrastructure game. Retrieved 27 November, 2010 from http://www.items-int.com/IMG/pdf/AGATI_Global_Forum_-_Ericsson_PA2.pdf

Archie, J., Barry, J., \& Olson, C. (2009). Protecting your rights in 140 characters or less: Trademark protection on Twitter. Intellectual Property and Technology Law Journal, 21(11), 23-26.

Ardichvili, A., Maurer, M., Li, W., Wntling, T., \& Stuedemann, R. (2006). Cultural influences on knowledge management through online communities of practice. Journal of Knowledge Management, 10(10), 94-107. Retrieved 6 November 2010 from http://mapule276883.pbworks.com/f/Cultural\%20influences\%20on\%20knowledge \%20sharing.pdf

Ashraf, B. (2009). Teaching the Google-eyed YouTube generation. Education \& Training, 51(56), 343352.

Arno, C. (2010). World Wide Web design: Hints and tips for designing a cross-cultural website. Tripwire Magazine. Retrieved 6 November 2010 from http://www.tripwiremagazine.com/2010/07/world-wideweb-design-hints-and-tips-for-designing-a-cross-cultural-website.html

Barsky, E., \& Purdon, M. (2006). Introducing WEB 2.0: social networking and social bookmarking for health librarians. JCHLA / JABSC, 27, 65-67.

Brown, J. S., Collins, A., \& Duguid, P. (1989). Situated cognition and the culture of learning. Educational Researcher, 18(1), 32-42. 
Burcher, N. (2010). Facebook usage statistics - March 2010. Retrieved 30 October 2010 from http://www.nickburcher.com/2010/03/facebook-usage-statistics-march-2010.html

Constantine, L. L. (2004). Beyond user-centered design and user experience: Designing for user performance. Cutter IT Journal, 17(2), 1-12.

Del Galdo, E .M. (1990). Internationalisation and translation: some guidelines for the design of humancomputer interfaces. In J. Nielsen (Ed), Designing user interfaces for international use (pp 1-10). Amsterdam: Elsevier Science Publishers.

Doyle, S. (2007). Software review: The role of social networks in marketing. Journal of Database Marketing and Customer Strategy Management, 15, 60-64.

Edutopia. (n.d.). How to use social networking technology. Retrieved 26 October, 2010 from http://www.edutopia.org/how-use-social-networking-technology

Faiola, A., \& Matei, S. A. (2005). Cultural cognitive style and web design: Beyond a behavioral inquiry into computer-mediated communication. Journal of Computer-Mediated Communication. Retrieved 6 November 2010, from http://jcmc.indiana.edu/voll1/issue1/faiola.html

Freeman, M., \& Blayney, P. (2005). Promoting interactive in-class learning environments: A comparison of an electronic response system with a traditional alternative. Proceedings of the $11^{\text {th }}$ Australasian Teaching Economics Conference.

Gagne, R. (1962). Military training and principles of learning. American Psychologist, 17, 263-276.

Gagne, R. (1985). The conditions of learning (4th ed.). New York: Holt, Rinehart \& Winston.

Gagne, R. (1987). Instructional technology foundations. Hillsdale, NJ: Lawrence Erlbaum Assoc.

Gagne, R., \& Driscoll, M. (1988). Essentials of learning for instruction (2nd Ed.). Englewood Cliffs, NJ: Prentice-Hall.

Gagne, R., Briggs, L., \& Wager, W. (1992). Principles of instructional design (4th Ed.). Fort Worth, TX: HBJ College Publishers.

George, R., Nesbitt, K., Maynard, J., \& Donovan, M. (2007). Capturing culture and community in the design of an indigenous website. IJDesign, 1-27. Retrieved 6 November 2010 from http://reecegeorge.com/Web_CultureCommunity.pdf

Hofstede, G. (1991). Cultures and organizations - Software of the mind. New York: Mc-Graw Hill.

Gibson, D. (2008). Culture, tradition, technology is school's innovative motto. Native Peoples Magazine, 21(5), 14.

Green, W., \& Ruyter, B. D. (n.d.). The design and evaluation of interactive systems with perceived social intelligence: Five challenges. Retrieved 6 November 2010 from http://boris.borderit.com/docs/SID08Green.pdf

Government du Quebec. Integrating the cultural dimension into school. Retrieved 6 November 2010 from http://www.mels.gouv.qc.ca/sections/cultureeducation/medias/99-6487-02A.pdf

Howe, N., \& Strauss, W. (2000). Millennials rising: The next great generation. New York: Vintage.

Johnson, D. (2009). Connections for learning: Schools and the educational use of social network. Retrieved 25 October, 2010 from https://saywire.com/downloads/Saywire-White-Paper.pdf

Kim, I., \& Kuljis, J. (2010). Manifestations of culture in website design. Journal of Computing and Information Technology, 18(2), 125-132.

Knowles, M. S. (1968). Andragogy, not pedagogy. Adult Leadership, 16(10), 350-352, 386.

Knowles, M. S. (1975). Self-directed learning: A guide for learners and teachers. Englewood Cliffs: Prentice Hall/Cambridge.

Knowles, M. S. (1977). The adult education movement in the United States. Malabar, FL: Krieger. 
Knowles, M. S. (1980). The modern practice of adult education: From pedagogy to andragogy. Englewood Cliffs: Prentice Hall/Cambridge.

Knowles, M. S., et al. (1984). Andragogy in action: Applying modern principles of adult education. San Francisco: Jossey-Bass.

Lave, J., \& Wenger, E. (1991). Situated learning: Legitimate peripheral participation. Cambridge, UK: Cambridge University Press.

Markussen, T., \& Krogh, P. G. (2008). Mapping cultural frame shifting in interaction design with blending theory. International Journal of Design, 22(2), 5-17.

Macvittie, L. (2010). Infrastructure $2.0+$ Cloud + IT as a service $=$ An architectural parfait. Retrieved 27 November, 2010 from http://cloudcomputing.sys-con.com/node/1535044

Margaryan, A., \& Littlejohn, A. (2008). Are digital natives a myth or reality? Students' use of technologies for learning. Retrieved 27 October, 2010 from http://www.academy.gcal.ac.uk/anoush/documents/DigitalNativesMythOrRealityMargaryanAndLittlejohn-draft-111208.pdf

Nickson, C. (2009). The history of social networking. Retrieved 30 October, 2010 from http://www.digitaltrends.com/features/the-history-of-social-networking

Oblinger, D., \& Oblinger, J. (2005). Is it age or IT: First steps towards understanding the net generation. In D. Oblinger \& J. Oblinger (Eds.), Educating the Net Generation (pp. 2.1-2.20). Boulder, CO: EDUCAUSE. Retrieved October 27, 2010, from http://www.educause.edu/educatingthenetgen

O'Reilly, T. (2004a). What is Web 2.0: Design patterns and business models for the next generation of software [online]. Retrieved 30 October, 2010 from http://www.oreillynet.com/pub/a/oreilly/tim/news/2005/09/30/what-is-web-20.html

O’Reilly, T. (2004b). The architecture of participation. Retrieved 30 October, 2010 from http://oreilly.com/pub/a/oreilly/tim/articles/architecture of participation.html

Oshlyansky, L. (2007). Cultural models in HCI: Hofstede, affordance and technology acceptance (Doctoral Dissertation). Retrieved 6 November 2010 from http://www-users.cs.york.ac.uk/ pcairns/PhD/LidiaPhD.pdf

Perdu. A. (2008). The history of Friendster. Retrieved 30 October, 2010 from http://webupon.com/socialnetworks/the-history-of-friendster

Prenksy, M. (2001). Digital natives, digital immigrants: Do they really think differently? On the Horizon, 9(6), 1-6.

Reedy, G. B. (2008). PowerPoint, interactive whiteboards, and the visual culture of technology in schools. Technology, Pedagogy \& Education, 17(2), 143-162.

Rogoff, B. (1990). Apprenticeship in thinking: Cognitive development in social context. New York: Oxford University Press.

Rubric for evaluating e-learning websites. Retrieved 6 November 2010 from http://www.trenton.k12.nj.us/mol/eckert/MOL\%20EDUC\%206309\%20WEBSITE/rubric\%20for\%20e valuation.htm .

Singel, R. (2010). Google Docs become any file as cloud wars heat up. Retrieved 26 October, 2010 from http://www.wired.com/epicenter/2010/01/google-docs-storag/

Social Media Graphics. (2010). Facebook compared to countries. Retrieved 28 October, 2010 from http://socialmediagraphics.posterous.com/facebook-compared-to-countries

Tan, F. B., \& Tung, L. L. (2003). Exploring website evaluation criteria using the repertory grid technique: A web designer's perspective. Proceedings of the Second Annual Workshop on HCI Research in MIS, Seattle, WA, December 12-13. Retrieved 6 November 2010 from http://sigs.aisnet.org/sighci/research/ICIS2003/HCI03_10.pdf 
Tapscott, D. (1998). Growing up digital: The rise of the Net Generation. New York: McGraw-Hill.

Tharp, R. G., \& Gallimore, R. (1988). Rousing minds to life: Teaching, learning and schooling in social context. New York: Cambridge University Press.

Thatcher, M. (2009). Using Web 2.0, open source technology and social networking services to facilitate collaboration and access to genealogy and local history information. IFLA, 23-27 August 2009, Milan, Italy.

Towell, L. (2009). The student-teacher digital divide and six new technology roller coaster rides. Distance Learning, 6(2), 53-57.

Vygotsky. L. S. (1978). Mind in society: the development of higher psychological processes. Cambridge, MA: Harvard University Press.

Vintere, A., \& Mljnovska, L. (2009). Changing the education culture through technology. Problems of Education in the $21^{\text {st }}$ Century, 13, 127-137.

Wertsch, V. (1991). Voices of the mind. Cambridge, MA: Harvard University Press.

Whipp, J., Eckman, E., \& van den Kieboom, L. (2005). Using sociocultural theory guide teacher use and integration of instructional technology in two professional development schools. Journal of Computing in Teacher Education, 22(1), 37-43. Retrieved 7 November 2010 from http://epublications.marquette.edu/cgi/viewcontent.cgi?article=1102\&context=edu fac

Wofle, A. (2010). Server Den asks Infoblox: What is infrastructure 2.0? Retrieved 27 November, 2010 from $\mathrm{http}: / / \mathrm{www}$.informationweek.com/news/globalcio/interviews/showArticle.jhtml?articleID $=222300500$

\section{Biography}

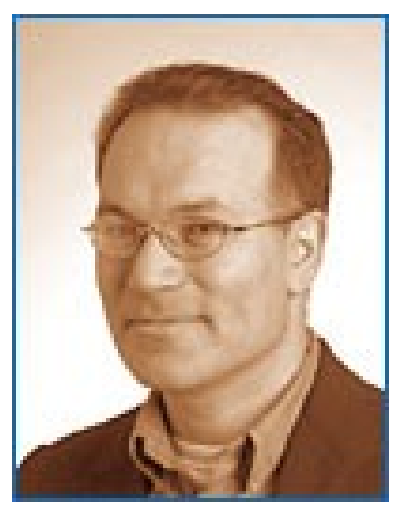

Dr. Anastasis Petrou is a Senior Lecturer at the University of East London where he lectures in the Information Technology and Digital Media Field in the School of Computing, IT and Engineering (CITE). $\mathrm{He}$ is a programme leader and he also leads on CITE's e-learning initiatives. 